\title{
Discussion on University Piano Teaching Based on Modern Educational Theory
}

\author{
Liu chao ${ }^{1, a}$ \\ ${ }^{1}$ Linyi University, Yishui,Shandong,276400 \\ a89671242@163.com
}

Keyword: theory of modern education; University piano teaching; application analysis

\begin{abstract}
In recent years, with the rapid development of economy, people's life level is gradually increasing. The pursuit of art is increased gradually. At the same time, the process of modernization of education reform is accelerating in our country, in order to conform to the trend of the present era development, modern piano teaching in university is important, because it is the era theme with the basic idea for social development. In piano teaching practice, the application of modern university teaching is taken into consideration, and the teaching mode has train a large number of complex piano professional talents. It also will push the modern education into the future with better and faster development. In this paper, the difference between the theory of modern education and traditional education is expounded firstly. The common features in the piano teaching are analyzed, and the training model is constructed. And then the main problems existing in the contemporary university for piano teaching are analyzed. Finally, the modern educational theory in application of piano teaching is discussed, the effective conclusions are obtained.
\end{abstract}

\section{Introduction}

In 21th Century, the reform of modern education is gradually promoted in China, along with the vigorous development of piano art education, modern universities pay high attention to university piano teaching, while the modern education theory is referred as a new teaching mode, it has been widely used in piano teaching of modern university, it has a substantial positive impact on the development of Chinese art education. Therefore, the modern education theory has a certain economic value and practical significance to University piano teaching[1].

\section{Difference between modern education and traditional education}

Generally speaking, there are some differences between modern education and traditional education, and these differences are shown as education thought, education objective, student oriented concept, teacher to student concept, teaching content, teaching methods and teaching process[2].

The theory of modern education has high degree of attention to the moral education, at the same time, the school education has paid important attention students' socialization education, the modern education theory is mainly established based on psychological logic and subject logic to a certain degree, the characteristics of the subject itself has good introduction meaning in the interest cultivation, interest and ability of piano training and learning are cultivated. The teaching objective of modern education theory has some respect for the personality of students on the one hand, and on the other hand, it provides substantive services for social reform and development of education. The personal value and social value are coordinated with the attention, to some extent, it is subjected to the principle of education principle, and the psychological development rule of students is followed[3]. Overall, the theory of modern education is taken as the new education, it focus on education at the same time, and the personality is taken more respect, development and interest cultivation are respected at the same time, the substantive reform of modern education is promoted[4], the education is the core of national economic development, so the national economic development is improved based on the modern education reform[5 7]. 


\section{General features analysis of piano teaching in university}

The so-called teaching model is mainly instructed by a certain education thought to some extent, around the teaching activity theme, the teaching activities are carried out, and then the stable system theory of teaching model is gradually formed, according to its nature, the important goal of this teaching mode is learning outcomes.

In the process of actual university piano teaching, it requires the teachers have some experience of playing, and the teachers should understand the music content comprehensively and fully, the university piano teaching can realize the best teaching effect fundamentally and truly. The evaluation standards are taken based on the student's performance in the real environment, for the realization of this process, it not only has a certain degree of sensibility, but also has a certain subjectivity. The teaching process requires students to play, on the other hand, the assessment and analysis of teacher to students are important, through some analysis and evaluation, and then some targeted exercises are taken, and the playing quality of students can be improved.

Generally speaking, in the University piano teaching, the traditional teaching mode processes the information directly. The teaching content focuses on linear tend development, the teaching modes have some types such as emotion teaching mode, behavior teaching mode, cognition teaching mode, and comprehensive teaching mode, etc. But these relatively traditional teaching modes often have some weakness problems, theses teaching modes cannot meet the development demands of modern teaching. With the rapid development of economy, our country music culture gradually increased, the University piano teaching is developed from the students' perspective, the economic development is taken as the orientation, and the subject has taken a great progress, the teaching mode will make full use of existing teaching resources, it pays more attention to students' personality and ability to some extent.

In one word, University piano teaching is referred as a specialized teaching, not only demands the piano teachers have professional teaching skills, it also demands the teachers have certain experience of playing in real hall. And the personality development of students are emphasized, encourage students to make appropriate innovation. To cultivate a large number of professionals in China, promote the stable development of our national economy.

\section{Existing problem in piano teaching}

Today, economy has been developing in China, at the same time the art education is obtained attention in high value. Especially for the university piano teaching, more and more people are pay attention to the university piano teaching subjects, the education reform is promoted, the basic idea of art education services is taken as the basis, the continuous innovation and reform of university teaching piano are proposed. But in fact, the contemporary university piano teaching has some problems, which are described as follows:

A. Lack of theoretical knowledge

In general, the music comes from life, but the modern university piano teaching lacks the theoretical knowledge, the practice teaching has a high degree attention in theory teaching, but the theory knowledge teaching is ignored. The teachers take finger law enforcement training to the students, although students' playing show ability is improved gradually, emotional grasp awareness is lack, it is hard to influence people truly to a certain extent.

B. Relatively simple way of learning

In the process of the piano learning, the teachers are paying much attention to the training of tune, its main teaching method is often explain the music and tune one by one, then the supervision of students self training is taken, it is inevitable that the students appear relatively irritable mood, so that the learning effect is relatively insufficient. The piano study interest is decreased to some extent.

C. Exist extreme sexual counseling

Generally speaking, students self-learning ability is relatively strong, but in the actual piano learning, professional guidance teachers are absent. In the teaching process, it is lack of substantial 
actual effectiveness, on one hand, teachers have relatively strict coaching attitude, on the other hand, the teachers often make the students have a great psychological dependence. Thus, their personality is missing, so that in the process of actual performance, students do not have their own unique personality.

Overall, the problems of contemporary university piano teaching are serious, and it is not limited as above, in the actual teaching process, there are still a variety of problems. Therefore, the school should improve the University piano teaching importance position, and the innovation and reform of teaching methods are promoted continuously, which will focus on improving the quality of University Teaching piano.

\section{Theory of modern education and application in University piano teaching}

Nowadays, many problems exist in the contemporary university piano teaching, it is shown as follows: teacher faculty is relatively weak, basic differences is big, and the mode of teaching is relatively backward. In order to enhance the practice of teaching in the University, on the basis of the current university piano teaching condition, the reform is deepen. With the help of modern education theory for University Piano Teaching, application of modern educational theory in University piano teaching mainly has following several points:

A. Application of modern educational theory in piano teaching in the University

Generally speaking, the modern education theory is shown as a kind of brand-new teaching idea, it will have some positive impact on deepening the reform of University piano teaching methods, advanced ideas and concepts are applied in the innovation of teaching mode. In the process of teaching concept reform, the concept of University piano teacher should be thoroughly changed, regular occupation training should be carried out for the teachers. On the other hand, the attitude of teachers need to be changed, the innovative teaching ideas should be protected, to play the main role of piano teachers. With the help of University piano teaching environment, digital media document and information technology are used, and the University piano teaching environment and conditions are improved, transformation is taken in deep extent.

B. Modern educational theory and application in the University piano teaching method reform

According to the practical application of modern educational theory in University piano teaching method, there are more positive innovations and reforms in the guide plane and teaching learning method cultivation. The whole process of University piano teaching content are fully grasped, students personality is respected greatly, the application of modern educational theory is researched in the University piano teaching method reform, the students' learning initiative can be improved, the students interest is cultivated, so the modern educational theory has a positive role in promoting the development of University piano teaching. Generally speaking, the important link of University piano teaching process is University piano performance technology, and yet at the same time, the piano grasping skill and the piano playing skills are important. The university piano teaching theory is taken based on modern education theory, and it should be combined with the teaching task, not only to have a practical understanding of theoretical knowledge in University piano classic works, but also should strengthen the cultivation of students' ability in piano performance. The main research direction is cultivation of college students' practical cognition to the piano playing skills. In the course of college students in piano playing, the permeability of emotional factors is important.

The modern educational theory is applied in the University piano teaching, so that theoretical knowledge and technical skills can be gasped by the students, and the independent thinking ability of students in learning the piano is cultivated. The new individual mode of university piano teaching is constructed.

C. Application of modern educational theory in the teaching mode of piano teaching in University

The application of modern education theory teaching in University piano teaching mode is shown as the teaching forms and organization change, and then adapts the theme of development in today. The Countermeasures and condition of College are combined, and then the piano teaching organization form of traditional university is changed and reformed. The enlarged enrollment pressure is eased. To the nature, in the process of the current university piano teaching, its teaching 
mode just focuses on student performance skills. It has no respect for the students' personality, so that the students depend on the teacher's teaching too much, and the single teaching mode makes students have a relatively low interest in learning. The modern education theory pays more attention to the cultivation of personality, more diversified and personalized teaching methods are formed. In the long-term mechanism of University piano teaching reform, the personality cultivation and the creativity ability cultivation are becoming more and more important. The proper innovation and reform University piano professional are developed, and the teaching content of University piano are evaluated comprehensively, to promote the development of music education. Overall, the application of modern educational theory in University piano teaching not only has a high attention to music quality of students, but also pays more attention to students' artistic accomplishment and the individuality development

\section{Conclusions}

With the rapid development of economy, the development of Chinese musical education is promoted, more and more people are paying more attention to the education reform and innovation, and focusing on improving the quality of teaching university piano teaching. On the basis of modern educational theory, the reform schemes of university piano teaching are discussed, with the development of music education, a large number of music professionals will be cultivated in China, the steady development of our national economy is promoted at the same time.

\section{References}

[1] STANKOVIC M S, JOHANSSON K H, STIPANOVIC D M. Distributed seeking of Nash equilibria with applications to mobile sensor networks[J]. IEEE Transaction on Automatic Control, 2012, 57(4):904-919.

[2] Han Mengjie, Zhang Dexiang. On Market Mechanism of Structural Changes in American Higher Education[J].Educational research, 2014,1:124-131.

[3] Yu Jia, Zhu Zhiqiang. Research On I-U-R Collaborative Innovation Based on Ecological Theory[J]. Bulletin of Science and Technology, 2013, 29(7): 225-230.

[4] Chen Guocai. Research on SilverLight Based WebGIS System and Its Application[J]. Bulletin of Science and Technology, 2013, 29(4): 177-179.

[5] QIU Jing, WANG Ping. Encryption Algorithm for Compressed Image Based on Chaotic Maps[J]. Computer Science, 2012, 39(6): 44-46.

[6] MING LI, KAI ZENG, WENJING LOU. Opportunistic Broadcast of Event-Driven Warning Messages in Vehicular Ad Hoc Networks with Lossy Links[J]. Computer Networks, 2011,55(10):2443-2464.

[7] Liu Xiangdong. Data Clustering Algorithm and Software Design Based on Disturbance Searching of Logistic Series[J]. Bulletin of Science and Technology, 2014,30(2): 161-163. 